Article

\title{
Fluid Inclusions at the Plavica Au-Ag-Cu Telescoped Porphyry-Epithermal System, Former Yugoslavian Republic of Macedonia (FYROM)
}

\author{
Vasilios Melfos ${ }^{1, *(\mathbb{D}}$, Panagiotis Voudouris ${ }^{2}$, , Todor Serafimovski $^{3}$ and Goran Tasev ${ }^{3}$ \\ 1 Department of Mineralogy, Petrology and Economic Geology, Aristotle University of Thessaloniki, \\ 54124 Thessaloniki, Greece \\ 2 Department of Mineralogy-Petrology, National and Kapodistrian University of Athens, 15784 Athens, \\ Greece; voudouris@geol.uoa.gr \\ 3 Department of Mineral Deposits, Faculty of Natural and Technical Sciences, University “Goce Delcev" Štip, \\ Goce Delcev 89, 2000 Štip, Macedonia; todor.serafimovski@ugd.edu.mk (T.S.); \\ goran.tasev@ugd.edu.mk (G.T.) \\ * Correspondence: melfosv@geo.auth.gr
}

Received: 18 December 2018; Accepted: 11 February 2019; Published: 14 February 2019

\begin{abstract}
The Plavica Au-Ag-Cu porphyry and high sulfidation (HS) epithermal deposit is located at the Kratovo-Zlatovo volcanic field in Eastern Former Yugoslavian Republic of Macedonia. In this study, new fluid inclusions data provide additional evidence of the presence of a porphyry style mineralization which is associated with an overlain HS epithermal deposit. The Oligocene-Miocene magmatic rocks have a calc-alkaline to high-K calc-alkaline affinity and consist of sub-volcanic intrusions and volcanic rocks. Previous studies distinguished four alteration types: (a) Sericitic, (b) advanced argillic, (c) silicification, and (d) propylitic alteration. Fluid inclusions showed an early magmatic brine in porphyry style veins with high salinity (33-57 $\mathrm{wt}^{\%} \mathrm{NaCl}$ equiv.), which coexists with a vapor rich fluid with lower salinity (14-20 $\mathrm{wt} \% \mathrm{NaCl}$ equiv.), at temperatures $380-500{ }^{\circ} \mathrm{C}$, under boiling conditions. At shallower depths, the fluid inclusions demonstrate various HS-epithermal deposits which were formed by moderate to low salinity (3-14 $\mathrm{wt} \% \mathrm{NaCl}$ equiv.) hydrothermal fluids at lower temperatures from 200 to $300^{\circ} \mathrm{C}$.
\end{abstract}

Keywords: Porphyry; epithermal; hypersaline fluid; boiling; Plavica

\section{Introduction}

High sulfidation (HS) epithermal deposits are temporally and genetically linked to intrusions that may be associated with deeper porphyry style mineralization [1-4]. Both styles of mineralization are found at subduction and post-subduction geotectonic settings and are related to the generation of hydrous calc-alkaline and alkaline magmas in convergent tectonic regimes [3,5,6]. Additionally, for these deposits, either a direct magmatic-hydrothermal contribution of precious metals or a remobilization of primary magmatic-hydrothermal ores under the influence of meteoric water-dominated convecting systems, has been proposed [7].

The ore deposits in the epithermal and porphyry environment are characterized by the distribution of hydrothermal alteration assemblages and ore minerals, which sometimes demonstrate zonation patterns. HS epithermal systems are commonly associated with lithocaps that are alteration domains with a horizontal to subhorizontal cover over intrusions. Lithocaps are characterized by two main hypogene alterations: Silicic (dominated by residual vuggy quartz) and advanced argillic (dominated by alunite, pyrophyllite, and dickite) alteration [4,7]. In volcanic centers, lithocaps are easy to find since they are erosional remnants and are typically prominent at the surface. The presence of lithocaps of 
large surface extent is a good indicator during exploration for deep deposits, because they may indicate extensive magmatic and hydrothermal activity and a potential for deeper porphyry and marginal epithermal vein mineralization [4].

However, lithocaps do not always show the exact location of the porphyry deposit in depth, due to the lack of directional indicators. This means that despite their potential for discovering deeper magmatic-hydrothermal deposits, their large areal extent (sometimes $>10 \mathrm{~km}$ in lateral dimensions and $>1 \mathrm{~km}$ thick) makes the exploration for porphyry mineralization typically difficult [4]. Sometimes the early, deep porphyry mineralization is overprinted or juxtaposed by late, shallow epithermal mineralization [8]. This process is called telescoping and is caused due to violent eruptions and the subsequent collapse of the paleosurfaces of the volcanoes.

A very good example of a HS epithermal mineralization associated with a porphyry style mineralization is the Plavica Au-Ag-Cu deposit in Eastern Former Yugoslavian Republic of Macedonia (FYROM). This deposit is located $5 \mathrm{~km}$ southwest of Kratovo and belongs to the Oligocene-Miocene Kratovo-Zlatovo volcanic complex (Figure 1). On the basis of the geological setting, mineralogical features, hydrothermal alteration, stable isotopes, and previous fluid inclusion studies, the Plavica deposit was considered as a typical example of a volcanic-hosted, HS epithermal deposit [9-15]. The close spatial and temporal relationship of the epithermal system with a porphyry deposit was recently documented by Serafimovski et al. [16,17].

Mining of copper and gold from pyrite-enargite veins in Plavica dates back to the Roman times, or even earlier at the time of Philip II (4th century BC). During the Ottoman period (15th-17th centuries), gold was extracted for coin production [18]. In 1934-1936, the British company "Selection Mines Ltd." carried out some exploration and further exploitation of the enargite veins with more than $2800 \mathrm{~m}$ of underground workings. Drilling exploration was undertaken by "Zletovo mine" and the National Geological Survey in Skopje in 1945-1952, 1961-1962, and 1963-1974. The National Geological Survey and the mining company "RIK Sileks" continued exploration during 1976-1986 with $30 \mathrm{~km}$ of drillings [19].

Since the late 1980s, further prospecting for $\mathrm{Cu}$ and $\mathrm{Au}$ has been carried out by "Cominco", "Cyprus Amax", "Minorco", "Goldfields", "Rio Tinto", and "European Minerals", with emphasis on gold which is associated with the peripheral silicified ore bodies (e.g., lithocaps). The latest exploration in the Plavica concession area was performed in 2011-2015 by the Australian company "Genesis Resources International Ltd." for several economically interesting commodities, such as $\mathrm{Au}, \mathrm{Cu}, \mathrm{Ag}$, $\mathrm{Mo}, \mathrm{Pb}$, and $\mathrm{Zn}$. The resources in Plavica have been calculated to $37.4 \mathrm{Mt}$ ore with $926 \mathrm{koz} \mathrm{Au}$ and $7.76 \mathrm{koz} \mathrm{Ag}$, using a gold cut-off grade of $0.4 \mathrm{ppm} \mathrm{Au} \mathrm{[20].}$

All those exploration projects contributed to a significant scientific database, which improved the knowledge about the geology of the Plavica HS epithermal type deposit [21-23], its geochemical features $[24,25]$, the hydrothermal alterations $[26,27]$ as well as the metallogenesis $[11,14,16,17,28]$. In addition, a fluid inclusion study by Alderton and Serafimovski [11] was conducted on samples from four drilling cores at the broader area of the HS epithermal deposit and estimated the formation conditions of the mineralization.

The purpose of the present work is the study of the fluid inclusions in additional samples from three drillings of the Plavica prospect, in order to verify the mineralogical and geochemical indication of a porphyry-type mineralization at the deep parts of Plavica hill, which was previously mentioned by other researchers $[11,17,29,30]$. Therefore, in this work, we present new fluid inclusions data and re-interpretation of the mineralogical composition of hydrothermal alteration assemblages and ore mineralization, which confirmed the presence of a porphyry style mineralization, associated with the HS epithermal deposit in Plavica. This study shows that detailed exploration for the discovery of new ore deposits requires a thorough fluid inclusion study that will interpret fluid phase relations and evaluate fluid characteristics in view of the ore forming conditions in the Serbo-Macedonian and the Rhodope metallogenic provinces [31]. 


\section{Geological Setting}

The Kratovo-Zletovo volcanic field is part of a NW-SE trending magmatic belt which extends for several hundred kilometers from Serbia, through FYROM, to Greece. Magmatic activity in this belt dates back in Eocene to Miocene and is associated with large ore deposits [9,10,32-34]. This metallogenic zone is called Lece-Buchim-Kilkis-Chalkidiki and is one of the most significant ore districts in SE Europe for future exploration for $\mathrm{Au}, \mathrm{Ag}, \mathrm{Cu}, \mathrm{Pb}, \mathrm{Zn}, \mathrm{Sb}$, and various rare and critical metals. The magmatic belt and the associated mineralization extend in the Serbo-Macedonian massif (Figure 1), between the Dinarides-Hellenides in the west and the Carpatho-Balkanides in the east. The geological structure of the region is closely related to the early stages of the Alpine orogeny, during the closure of the Tethys ocean and the subsequent subduction of the ocean lithosphere below the Eurasian plate $[9,33,34]$.

The Plavica Au-Ag-Cu deposit is located in the Probištip basin, which is controlled by extended faults and hosts intercalations of magmatic and sedimentary rocks with $\sim 1 \mathrm{~km}$ in thickness. The crystalline basement in the area consists of schists and amphibolites of the Serbo-Macedonian massif with a Pre-Cambrian to Palaeozoic age. The magmatic rocks are calc-alkaline to high-K calc-alkaline in character and have an Oligocene-Miocene age. They consist of sub-volcanic intrusions (granodiorites, quartz-monzonites, and quartz-diorites) and volcanic rocks such as trachyandesites, andesites, basaltic trachyandesites, dacites, and trachytes occurring as lava flows, stocks, dykes, ignimbrites, breccias and ash, lapilli and crystal tuffs (Figure 1) [35,36]. K-Ar and $\mathrm{Rb}-\mathrm{Sr}$ ages of andesites at the deposit are $26.5 \pm 2 \mathrm{Ma}$ [10].

According to Serafomovski [10], Alderton and Serafimovski [11]. Stefanova et al. [13], Zlatkov et al. [14], and Serafimovski et al. [17], structural and geomorphological characteristics of the basin show a concentric, arcuate structure around the Plavica deposit, suggesting the presence of a small caldera $\sim 1.5 \mathrm{~km}$ across. Moreover, there are abundant mineralized fractures with a NW-SE, ENE-WSW and E-W strike [10,23,37] (Figure 1).

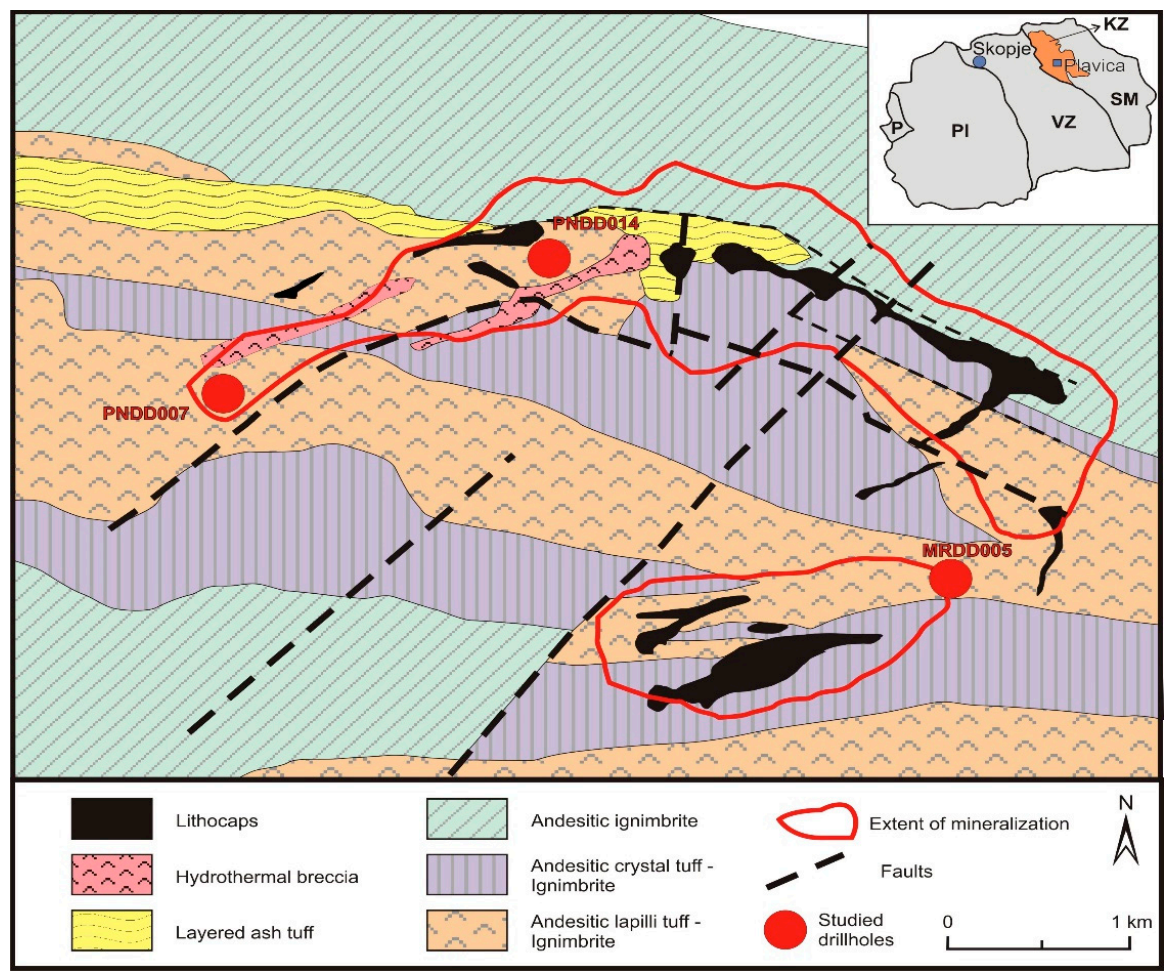

Figure 1. Simplified geological map of the Plavica area, based on Alderton and Serafimovski [11] and Reid et al. [38]. KZ: Kratovo-Zletovo volcanic field, P: Pindos zone, Pl: Pelagonian zone, VZ: Vardar zone, SM: Serbo-Macedonian massif. 
Alteration of the volcanic rocks is intense in the central part of the deposit and in the vicinity of the lithocaps. Previous studies of the hydrothermal alteration in Plavica [9-11,17] distinguished four alteration types: (a) Sericitic alteration, with sericite and quartz, plus minor titanite, tourmaline, barite, and adularia; (b) advanced argillic alteration, characterized by kaolinite, alunite, zunyite, pyrophyllite, diaspore, and corundum; (c) silicification, which is widespread, particularly as massive replacement silica bodies with evident vuggy silica (Figure 2a), forming characteristic lithocaps that are laterally and vertically extensive; (d) propylitic alteration, with chlorite, epidote, sericite, calcite, rutile, and magnetite. A zonation of these alteration types is apparent, with sericitic alteration covering the central and deeper parts of the deposit and the advanced argillic alteration occurring in the surrounding areas, including mainly the lithocaps. Propylitic alteration is observed in the andesites (Figure $2 b$ ) at the periphery of the deposit, outside the studied area.

The lithocaps in Plavica have a significant distribution, at the highest levels of the ore deposit, and stick out of the ground in the form of steep cliffs. Those lithocaps occur in two elongated zones: The northern and the southern zone (Figure 1) [39]. Towards the east, the lithocaps contain significant amount of alunite-quartz alteration (Figure 2c). Gold grades in the lithocaps reach up to $3.0 \mathrm{~g} / \mathrm{t}$ [25]. The mineralization and the intensive hydrothermal alteration exceed $1000 \mathrm{~m}$ in depth [23]. The 3D model of $\mathrm{Au}$ and $\mathrm{Cu}$ distribution has shown an isometric to lens and lensoid morphology, with an increase of a ductile deformation as the depth increases [15].

Ore minerals at Plavica has been studied by several authors (e.g., [11-15,17]). They have distinguished four types of mineralization: (a) A porphyry style stockwork and disseminated $\mathrm{Cu}-\mathrm{Au}$ (Mo, Ag) mineralization which occurs in the central and deepest part of the system; (b) quartz veins with pyrite, sphalerite, enargite, and \pm gold, which occur at the intermediate levels and are superimposed on the stockworks; (c) massive, brecciated, and vuggy silica bodies enriched in Au reaching up to $10 \mathrm{~g} / \mathrm{t}$, with quartz, opal, alunite, kaolinite, jarosite, and sulfur, at the periphery of the central zone. These bodies mostly have a maximum development at depths of $100 \mathrm{~m}$ but may extend to greater depths reaching up to $400 \mathrm{~m}$; (d) $\mathrm{Pb}-\mathrm{Zn}$ veins which extend from the periphery of the ore system, around the margins of the caldera. Hydrothermal breccias are common in Plavica and consist mainly of alunite, quartz, and ore minerals (Figure $2 \mathrm{~d}$ ).

The mineral assemblages of (a) disseminated and (b) vein type mineralization at the Plavica deposit are complex, and several paragenetic stages have been suggested [11-17]. The ore minerals include pyrrhotite, pyrite, chalcopyrite, bornite, molybdenite, magnetite, hematite, rutile, scheelite, sphalerite, galena, tennantite-tetrahedrite (Figure 2e,f), enargite, luzonite, famatinite, seligmannite, chalcocite, proustite, pearceite, melnikovite, petzite, bogdanovite, bezsmertnovite, sylvanite, bilibinskite, and native gold [11-17]. Supergene processes in the upper part of the deposit led to the formation of malachite, azurite, smithsonite, anglesite, cerussite, chalcocite, digenite, covellite (Figure 2e,f), native copper, hematite, and hydrated Fe- and Mn-oxides [11-17].

The age of the advanced argillic alteration in Plavica was determined by ${ }^{40} \mathrm{Ar} /{ }^{39} \mathrm{Ar}$ in alunite, demonstrating an exact age range of 25.50-25.83 $\pm 0.38 \mathrm{Ma}$, whereas the host volcanic rocks have been dated by $\mathrm{U}-\mathrm{Pb}$ in zircons at $27 \mathrm{Ma}$ [38]. According to Alderton and Serafimovski [11], stable isotopes in quartz showed a narrow range of $\delta^{18} \mathrm{O}$, from 12.71 to $15.41 \%$ SMOW (Standard Mean Ocean Water), which is typical of volcanic-hosted precious metal deposits. The $\delta^{18} \mathrm{O}$ fluid composition calculated for an assumed constant temperature of $250{ }^{\circ} \mathrm{C}$ falls in a range of 3.74-6.44\% SMOW, indicative of a mixed magmatic-meteoric water system. These fluid values are similar to HS deposits, with a high portion of magmatic fluid $[1,40,41]$. Sulfur isotopes in selected vein minerals (pyrite, galena, enargite) showed small variations in $\delta^{34} \mathrm{~S}$ values, from -4.1 to $+0.6 \%$ CDT (Canyon Diablo Troilite), with most values gathering near $0 \%$. This $\mathrm{S}$ isotopic signature indicates a magmatic source for sulfur [11]. 

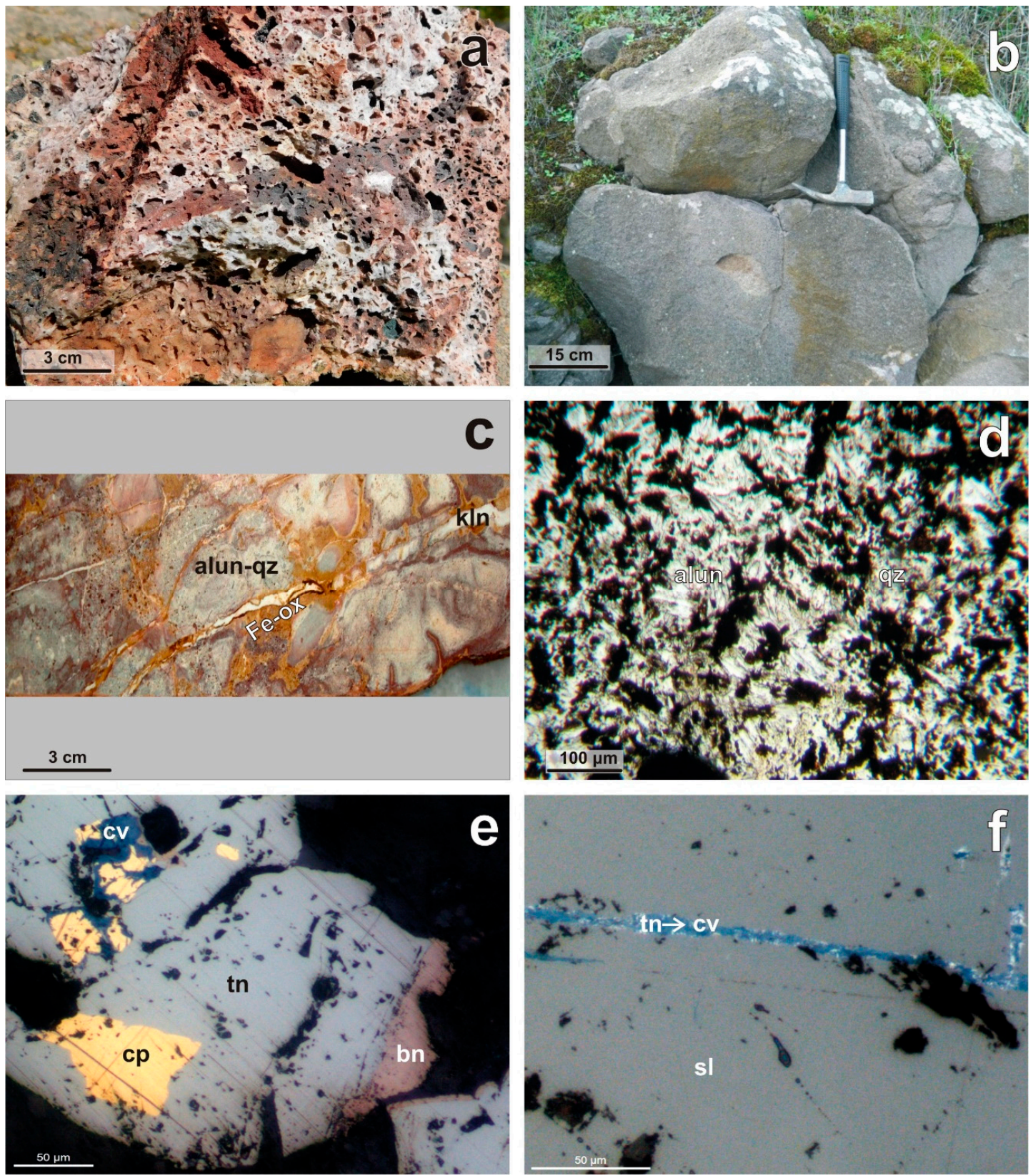

Figure 2. Photographs of the products of hydrothermal alteration of rocks and the ore minerals in Plavica. (a) Vuggy silica, which is widespread, particularly as replacement of massive silica bodies. (b) Propylitized andesite at the periphery of the deposit. (c) Brecciated volcanic tuff which was altered to alunite-quartz (alun-qz), with Fe-oxides and Fe-hydroxides (Fe-ox) cross-cut by kaolinite (kln). (d) Photomicrograph of quartz (qz) and alunite (alun) alteration of the volcanic tuff with Fe-hydroxides (dark); (transmitted light, plane polarized). (e) Photomicrograph of bornite (bn), tennantite (tn), and chalcopyrite (cp), which is partly replaced by covellite (cv); (reflected light, plane polarized). (f) Photomicrograph of sphalerite (sl) crosscut by a tennantite (tn), which is replaced by covellite (cv) (reflected light, plane polarized).

\section{Sampling and Methods of Analyses}

A total of five samples from three drill holes located at different parts of the Plavica deposit were studied in this work (Figure 1). This study aimed at improving the suggested metallogenic models for Plavica system, despite the restricted number of the samples. For this reason, two samples were obtained from the drill hole PNDD014 $(42.045344,22.164689)$ at the depths of $126 \mathrm{~m}$ (PLV 3581) and 
$480 \mathrm{~m}$ (PLV 3583). Two additional samples came from the borehole PNDD007 at the depth of $238 \mathrm{~m}$ (PLV 3590) and $265 \mathrm{~m}$ (PLV 3591). The last studied sample was taken from the borehole MRDD005 $(42.041089,22.181598)$ at the depth of $40 \mathrm{~m}$ (PLV 3586).

All the samples, apart from sample PLV 3583, were from low depths, up to $265 \mathrm{~m}$. At those low depths, the drillings have penetrated mainly the andesitic tuffs and ignimbrites which host the epithermal type mineralization. Sampling focused on the mineralized hydrothermal quartz, which forms small veinlets or disseminations within these volcanic rocks (Figure 3a-c). The sample PLV 3583 is from the deeper part of the Plavica system, at $460 \mathrm{~m}$, where a porphyry granodiorite intrusion with a porphyry style mineralization is crosscut by quartz veins and veinlets (Figure $3 \mathrm{~d}$ ).
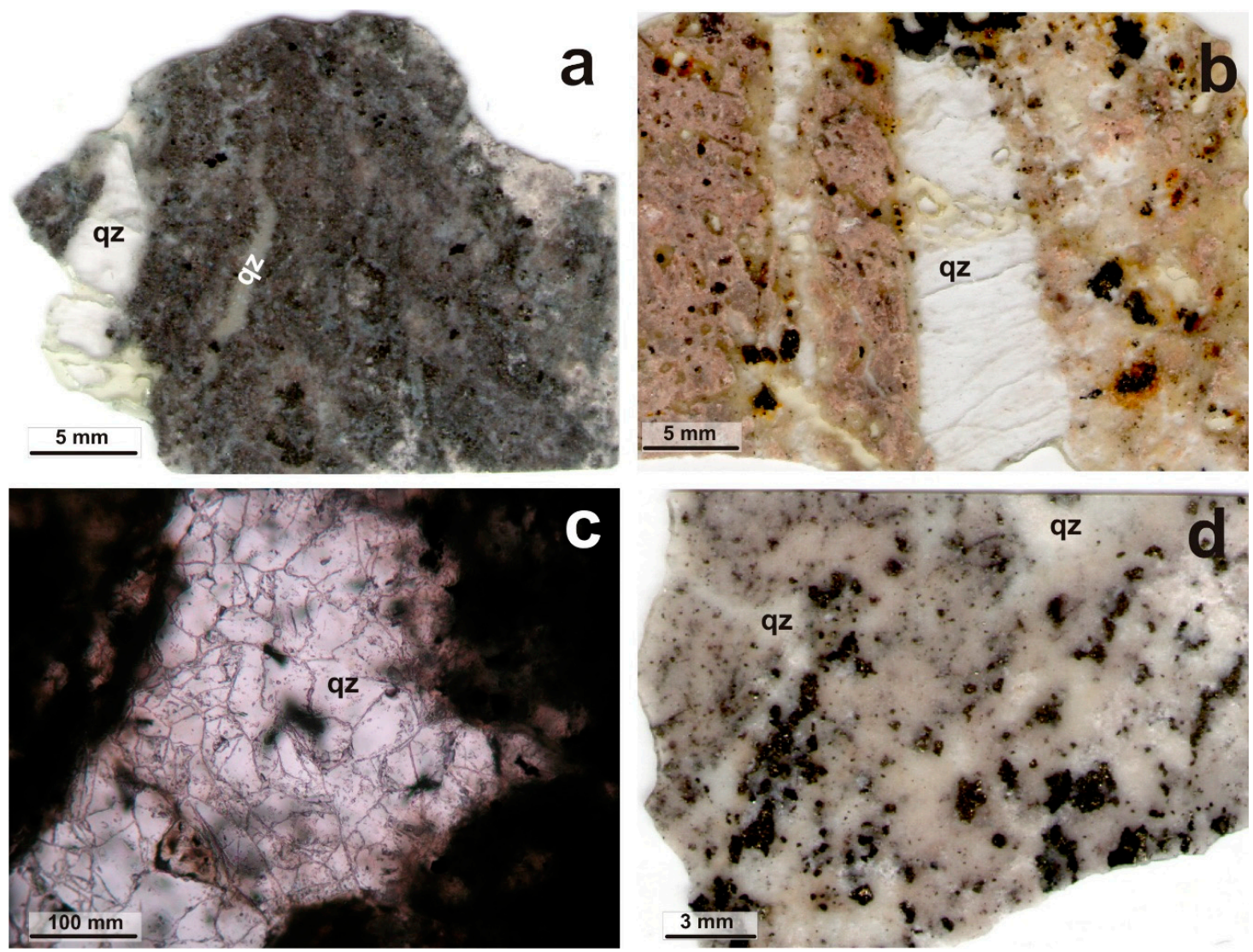

Figure 3. Photographs of the studied samples in Plavica. (a) and (b) Epithermal quartz (qz) veins crosscutting the argillized andesitic tuffs with ore mineralization (samples PLV 3581 and PLV 3591, respectively). (c) Transparent equigranular quartz grains (qz) in an epithermal veinlet crosscutting the andesitic tuff (sample PLV 3586) (transmitted light, plane polarized). (d) Quartz (qz) veinlets crosscutting the porphyry granodiorite with ore mineralization (sample PLV 3583).

Three other samples (PLV 3578, PLV 3580, PLV 3587) that were collected from Plavica mineralization were not suitable for fluid inclusion studies due to the lack of proper inclusions for heating/freezing measurements.

In the present study, fluid inclusion spatial relationships and phase changes within the inclusions during heating and freezing runs were studied in hydrothermal quartz. Microthermometric measurements were carried out on 312 fluid inclusions in doubly polished wafers at the Department of Mineralogy, Petrology and Economic Geology at Aristotle University of Thessaloniki (Greece), with a LINKAM THM-600/TMS 90 heating-freezing stage coupled to a Leitz SM-LUX-POL microscope. Calibration of the stage was achieved using organic standards with known melting points and ice $\left(\mathrm{H}_{2} \mathrm{O}\right)$. The precision of the heating and freezing measurements was $\pm 1{ }^{\circ} \mathrm{C}$ and $\pm 0.2^{\circ} \mathrm{C}$, respectively. 
Fluid compositions and properties were derived from the computer program "FLINCOR" [42] based on equations of Bodnar [43] in the system $\mathrm{H}_{2} \mathrm{O}-\mathrm{NaCl}$.

\section{Fluid Inclusions Data}

\subsection{Previous Fluid Inclusion Studies}

A preliminary fluid inclusions study in hydrothermal quartz of the HS epithermal system in Plavica was carried by Alderton and Serafimovski [11] who mainly recognized two-phase aqueous vapor-rich inclusions. In rare cases, quartz also contained two-phase aqueous liquid-rich inclusions and three-phase liquid-rich inclusions with a halite solid phase. The homogenization temperature data suggested that boiling began when temperatures exceeded $\sim 200^{\circ} \mathrm{C}$, assuming near-hydrostatic conditions. During boiling, the temperatures reached at least $250-300{ }^{\circ} \mathrm{C}$ and then decreased to $<70{ }^{\circ} \mathrm{C}$, leading to later stages of hydrothermal activity.

Alderton and Serafimovski [11] suggested three mechanisms for ore deposition and speculated the exsolution of a magmatic fluid from a buried stock, which subsequently separated into a low density vapor and a saline brine: (a) Acidification could lead to precipitation of $\mathrm{Au}$, (b) boiling and loss of $\mathrm{CO}_{2}$ would cause an increase in $\mathrm{pH}$ and precipitation of $\mathrm{Cu}$, and (c) mixing with meteoric fluids in the upper parts of this system was widespread.

\subsection{Morphology and Types of Fluid Inclusions}

Quartz in the studied samples was distinguished under optical microscope in two types: A recrystallized transparent quartz which predates the ore mineralization and is free of fluid inclusions, and a clear granular quartz, sometimes euhedral, which was formed contemporaneously with the ore, being in equilibrium with the ore minerals. This quartz type contains fluid inclusions which were suitable for microthermometric measurements.

The fluid inclusions are either found isolated along the quartz growth zones or are arranged in clusters and planes along healed cracks. On the basis of the criteria suggested by the authors of $[44,45]$, they are considered to be primary or secondary, respectively. The shape of the studied fluid inclusions is rounded to elongate, and only rarely do they demonstrate "negative crystals". Negative crystal shapes are common for many natural fluid inclusions and represent cavities that tend to form crystal phases due to recrystallization or dissolution processes [44]. The maximum length of the studied fluid inclusions is $45 \mu \mathrm{m}$.

Four types of primary fluid inclusions were identified in Plavica depending on the phase ratios observed at room temperature and their behavior during freezing and heating experiments. Type 1 , two-phase aqueous inclusions contain a vapor bubble occupying 10 to $20 \mathrm{vol} \%$ (Figure $4 \mathrm{a}$ ) and homogenize into the liquid phase. Type 2 fluid inclusions contain a liquid phase, a vapor bubble occupying 10 to $20 \mathrm{vol} \%$, and a colorless isotropic daughter mineral identified as halite $(\mathrm{NaCl}$; Figure $4 \mathrm{~b}$ ). They mainly homogenize either by bubble disappearance or very rarely by dissolution of the halite. Two-phase type 3 inclusions contain a large vapor bubble ( $~ 80 \mathrm{vol} \%)$ and a liquid phase (Figure $4 \mathrm{c}$ ) and homogenize into the vapor state. The least common are the type 4 aqueous inclusions that are dominated by a vapor bubble ( $80-90 \mathrm{vol} \%$ ) and a halite crystal (Figure $4 \mathrm{~d}$ ). They homogenize only by bubble disappearance. It is very possible that the type 4 inclusions trapped a halite crystal along with the vapor. However, post-trapping re-equilibration with vapor loss or volume shrinkage due to necking and/or stretching of the inclusions cannot be excluded, although there is not any clear evidence for post-trapping processes. 

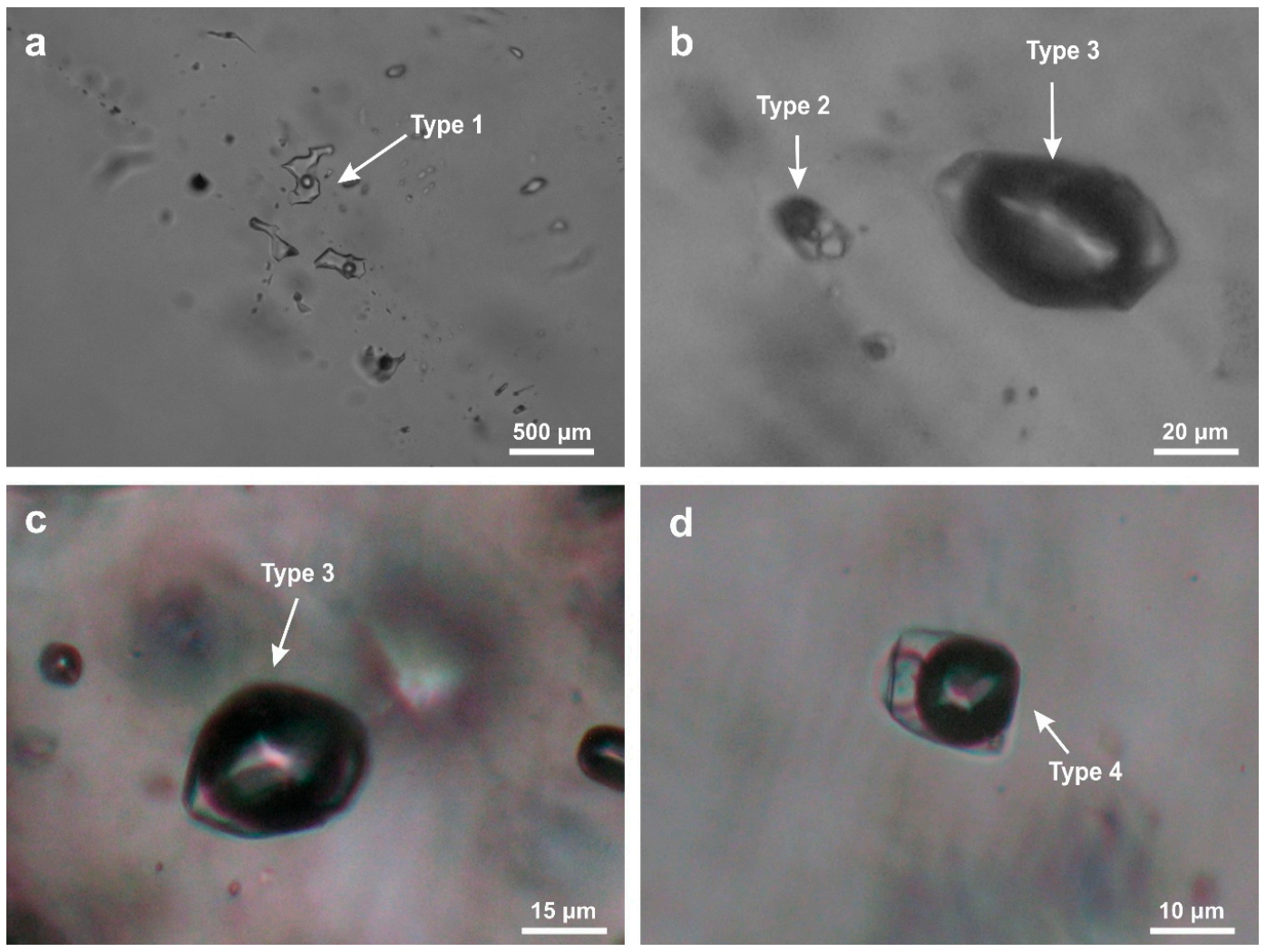

Figure 4. Fluid inclusions in quartz from the Plavica ore deposit. (a) Type 1 fluid inclusion from the proximal high sulfidation (HS) epithermal style mineralization (sample PLV 3590). (b) Co-existing types 2 and 3 fluid inclusions at the porphyry style mineralization (sample PLV 3583). (c) Type 3 fluid inclusion from the porphyry style mineralization (sample PLV 3583). (d) Rare type 4 fluid inclusion from the porphyry style mineralization (sample PLV 3583).

In some cases, one-phase inclusions containing only a vapor phase were observed in quartz. They are mainly found along microcracks and are possibly attributed to volume changes of the inclusions through a "stretching" process. Stretching is a post-entrapment modification of fluid inclusions along healed microcracks due to mechanical intracrystalline strain. A characteristic of the fluid inclusions of all types is that they occasionally contain an opaque mineral phase (probably pyrite or chalcopyrite).

Interpretation of the fluid inclusions was based on fluid inclusion clusters that occur within a limited area in parts of quartz which escaped recrystallization [45]. On the basis of the criteria suggested by Bodnar [45], two discrete primary fluid inclusion clusters were identified. The first group is characterized by type 1 inclusions, which exist in all samples of the epithermal mineralization (PLV 3581, PLV 3590, PLV 3591, and PLV 3586). The second group is related with the porphyry style mineralization and contains inclusions of type 1,2,3, and 4 . This cluster is found only in the sample PLV 3583 from the drill hole PNDD014 at the depth of $480 \mathrm{~m}$. The absence of liquid $\mathrm{CO}_{2}$ or clathrate formation during freezing experiments suggests that the fluid inclusions do not contain any $\mathrm{CO}_{2}$.

\section{Microthermometry}

Results of the microthermometric determinations in the samples from Plavica are summarized in Table 1. On the basis of the fluid inclusions characteristics and the microthermometric data, the samples represent different parts of the Plavica ore system, including the porphyry style mineralization (PLV 3583), the telescoped HS epithermal mineralization (PLV 3581) above the porphyry mineralization, and the proximal (PLV 3590, PLV 3591) and the distal (PLV 3586) HS epithermal mineralizations related to the porphyry mineralization. 
Table 1. Fluid inclusion data for quartz in the porphyry-HS epithermal styles mineralization at Plavica. D-HS Epithermal: Distal HS epithermal mineralization; P-HS Epithermal: Proximal HS epithermal mineralization, related to the porphyry style mineralization; T-HS Epithermal: Telescoped HS epithermal mineralization; Qtz: Quartz; L: Liquid; V: Vapor; S: Solid phase of halite; n: Number of measurements.

\begin{tabular}{|c|c|c|c|c|c|c|c|c|}
\hline Sample & $\begin{array}{c}\text { Drill hole } \\
\text { (Elevation) }\end{array}$ & Host Mineral & Ore Style & $\begin{array}{c}\text { Fluid } \\
\text { Inclusions } \\
\text { Character }\end{array}$ & $\begin{array}{c}\text { Fluid Inclusion Type } \\
\text { (Homogenize to } \\
\text { Phase) }\end{array}$ & $\begin{array}{c}\text { Homogenization } \\
\text { Temperature }\left({ }^{\circ} \mathrm{C}\right) \\
\text { Range }\end{array}$ & $\begin{array}{c}\text { Final Melting } \\
\text { Temperature }\left({ }^{\circ} \mathrm{C}\right) \\
\text { Range }\end{array}$ & $\begin{array}{c}\text { Salinity (wt } \% \\
\text { NaCl Equiv.) } \\
\text { Range }\end{array}$ \\
\hline PLV 3586 & $\begin{array}{l}\text { MRDD005 } \\
(40.6 \mathrm{~m})\end{array}$ & Qtz & $\begin{array}{c}\text { D-HS } \\
\text { sulfidation } \\
\text { epithermal }\end{array}$ & Primary & $1 \mathrm{~L}+\mathrm{V} \rightarrow \mathrm{L}$ & $200-294(n=46)$ & -3.82 to $-2.03(n=46)$ & $3.33-6.11$ \\
\hline PLV 3590 & $\begin{array}{l}\text { PNDD007 } \\
(238.9 \mathrm{~m})\end{array}$ & Qtz & $\begin{array}{c}\text { P-HS sulfidation } \\
\text { epithermal }\end{array}$ & Primary & $1 \mathrm{~L}+\mathrm{V} \rightarrow \mathrm{L}$ & $208-251(n=33)$ & -9.67 to $-5.49(n=33)$ & $8.50-13.59$ \\
\hline PLV 3591 & $\begin{array}{l}\text { PNDD007 } \\
(265 \mathrm{~m})\end{array}$ & Qtz & $\begin{array}{c}\text { P-HS sulfidation } \\
\text { epithermal }\end{array}$ & Primary & $1 \mathrm{~L}+\mathrm{V} \rightarrow \mathrm{L}$ & $208-258(n=30)$ & -9.02 to $-6.42(n=30)$ & $9.74-12.88$ \\
\hline PLV 3581 & $\begin{array}{l}\text { PNDD014 } \\
(126 \mathrm{~m})\end{array}$ & Qtz & $\begin{array}{l}\text { T-HS sulfidation } \\
\text { epithermal }\end{array}$ & Primary & $1 \mathrm{~L}+\mathrm{V} \rightarrow \mathrm{L}$ & $240-307(n=22)$ & -9.35 to $-4.60(n=22)$ & $7.25-13.24$ \\
\hline PLV 3583 & $\begin{array}{l}\text { PNDD014 } \\
(460 \mathrm{~m})\end{array}$ & Qtz & Porphyry & Primary & $\begin{array}{c}1 \mathrm{~L}+\mathrm{V} \rightarrow \mathrm{L} \\
2 \mathrm{~L}+\mathrm{V}+\mathrm{S} \rightarrow \mathrm{L} \\
3 \mathrm{~L}+\mathrm{V} \rightarrow \mathrm{V} \\
4 \mathrm{~L}+\mathrm{V}+\mathrm{S} \rightarrow \mathrm{V}\end{array}$ & $\begin{array}{c}358-515(n=47) \\
337-476(n=57) \\
340-522(n=32) \\
457-485(n=4)\end{array}$ & $\begin{array}{c}-16.78 \text { to }-9.67(n=36) \\
223-413(n=57) \\
-16.57 \text { to }-11.63(n=9) \\
423-461(n=4)\end{array}$ & $\begin{array}{c}13.59-19.9 \\
33-51 \\
15.60-19.87 \\
50-57\end{array}$ \\
\hline
\end{tabular}




\subsection{Microthermometric Data for the Telescoped Porphyry-Epithermal Style Mineralization}

Initial ice melting temperatures (Te) of fluid inclusions in the porphyry style mineralization (sample PLV 3583) vary from -54 to $-35^{\circ} \mathrm{C}$, suggesting a diversity of the dissolved salts including $\mathrm{NaCl}, \mathrm{CaCl}_{2}, \mathrm{KCl}, \mathrm{MgCl}_{2}$, and $\mathrm{FeCl}_{2}$ in various concentrations. The observed Te may be compared with the initial ice melting temperatures for the systems of $\mathrm{H}_{2} \mathrm{O}-\mathrm{NaCl}-\mathrm{MgCl}_{2}\left(\mathrm{Te}=-35.0{ }^{\circ} \mathrm{C}\right)$, $\mathrm{H}_{2} \mathrm{O}-\mathrm{NaCl}-\mathrm{FeCl}_{2}\left(\mathrm{Te}=-37.0^{\circ} \mathrm{C}\right), \mathrm{H}_{2} \mathrm{O}-\mathrm{CaCl}_{2}\left(\mathrm{Te}=-49.5^{\circ} \mathrm{C}\right), \mathrm{H}_{2} \mathrm{O}-\mathrm{KCl}-\mathrm{CaCl}_{2}\left(\mathrm{Te}=-50.5^{\circ} \mathrm{C}\right)$, $\mathrm{H}_{2} \mathrm{O}-\mathrm{MgCl}_{2}-\mathrm{CaCl}_{2}\left(\mathrm{Te}=-52.2{ }^{\circ} \mathrm{C}\right)$, and $\mathrm{H}_{2} \mathrm{O}-\mathrm{NaCl}_{2}-\mathrm{CaCl}_{2}\left(\mathrm{Te}=-55.0^{\circ} \mathrm{C}\right)$ [46]. Final ice melting temperatures of type 1 inclusions ranged from -16.78 to $-9.67^{\circ} \mathrm{C}$, indicating that they have salinities of $13.59-19.96 \mathrm{wt} \% \mathrm{NaCl}$ equiv. [43,47]. Dissolution temperatures of halite in the type 2 inclusions $\left(223-413{ }^{\circ} \mathrm{C}\right)$ indicated brine salinities ranging from 33.09 to $50.73 \mathrm{wt} \% \mathrm{NaCl}$ equiv. The salinity of type 3 inclusions, on the basis of freezing point depression $\left(-16.57\right.$ to $\left.-11.63{ }^{\circ} \mathrm{C}\right)$, ranged from 15.60 to $19.87 \mathrm{wt} \% \mathrm{NaCl}$ equiv. Type 4 fluid inclusions showed halite dissolving at temperatures between 423 and $461{ }^{\circ} \mathrm{C}$, which indicates salinities from 50.30 to $56.64 \mathrm{wt} \% \mathrm{NaCl}$ equiv.

Homogenization temperatures (Th) for type 1 inclusions in quartz from the porphyry style mineralization ranged from 358 to $515{ }^{\circ} \mathrm{C}$ (Figure 5). Type 2 fluid inclusions homogenized to the liquid phase and the last disappearing phase was vapor or halite, at temperatures from 337 to $476{ }^{\circ} \mathrm{C}$. Homogenization temperatures of type 3 inclusions ranged from 340 to $522^{\circ} \mathrm{C}$ and of type 4 between 457 and $485^{\circ} \mathrm{C}$ (Figure 5). The majority of the homogenization temperatures of the inclusions from the porphyry style mineralization range between 380 and $500{ }^{\circ} \mathrm{C}$, with a distinct maximum at $440{ }^{\circ} \mathrm{C}$ (Figure 5).

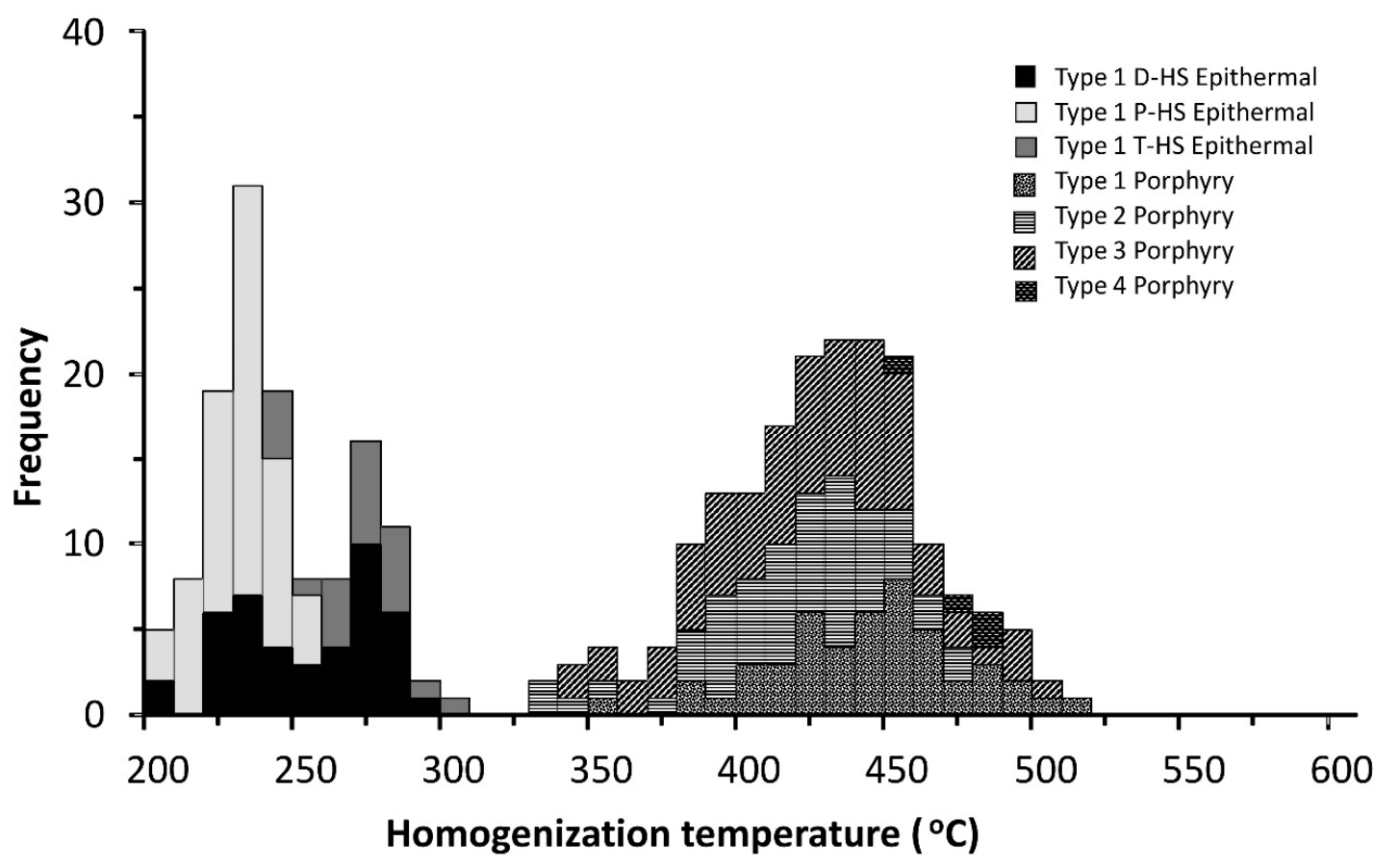

Figure 5. Homogenization temperatures of the fluid inclusions from the porphyry-HS epithermal styles mineralization at Plavica. T-HS Epithermal: Telescoped HS epithermal mineralization; P-HS Epithermal: Proximal HS epithermal mineralization, related to the porphyry style mineralization; D-HS Epithermal: Distal HS epithermal mineralization.

A plot of homogenization temperatures versus salinity (Figure 6) of fluid inclusions in quartz from the porphyry style mineralization shows that there are two populations of fluid inclusions that exhibit similar homogenization temperatures $\left(340-522^{\circ} \mathrm{C}\right)$, but different salinities. Type 1 and 3 inclusions with moderate salinities (13.59 to $19.96 \mathrm{wt} \% \mathrm{NaCl}$ equiv.) and type 2 and 4 inclusions with high salinity (33.09 to $56.64 \mathrm{wt} \% \mathrm{NaCl}$ equiv.) have a clear gap in salinity between 20 and $33 \mathrm{wt} \% \mathrm{NaCl}$ equiv. 
This suggests a heterogeneous trapping of both phases of a boiling fluid during the porphyry style ore formation in Plavica $[44,48]$. The estimated densities are $>0.85 \mathrm{~g} \cdot \mathrm{cm}^{-3}$ for the high-salinity fluids (type 2 ), and $<0.78 \mathrm{~g} \cdot \mathrm{cm}^{-3}$ for the moderately saline vapor-rich fluids (type 3 ).

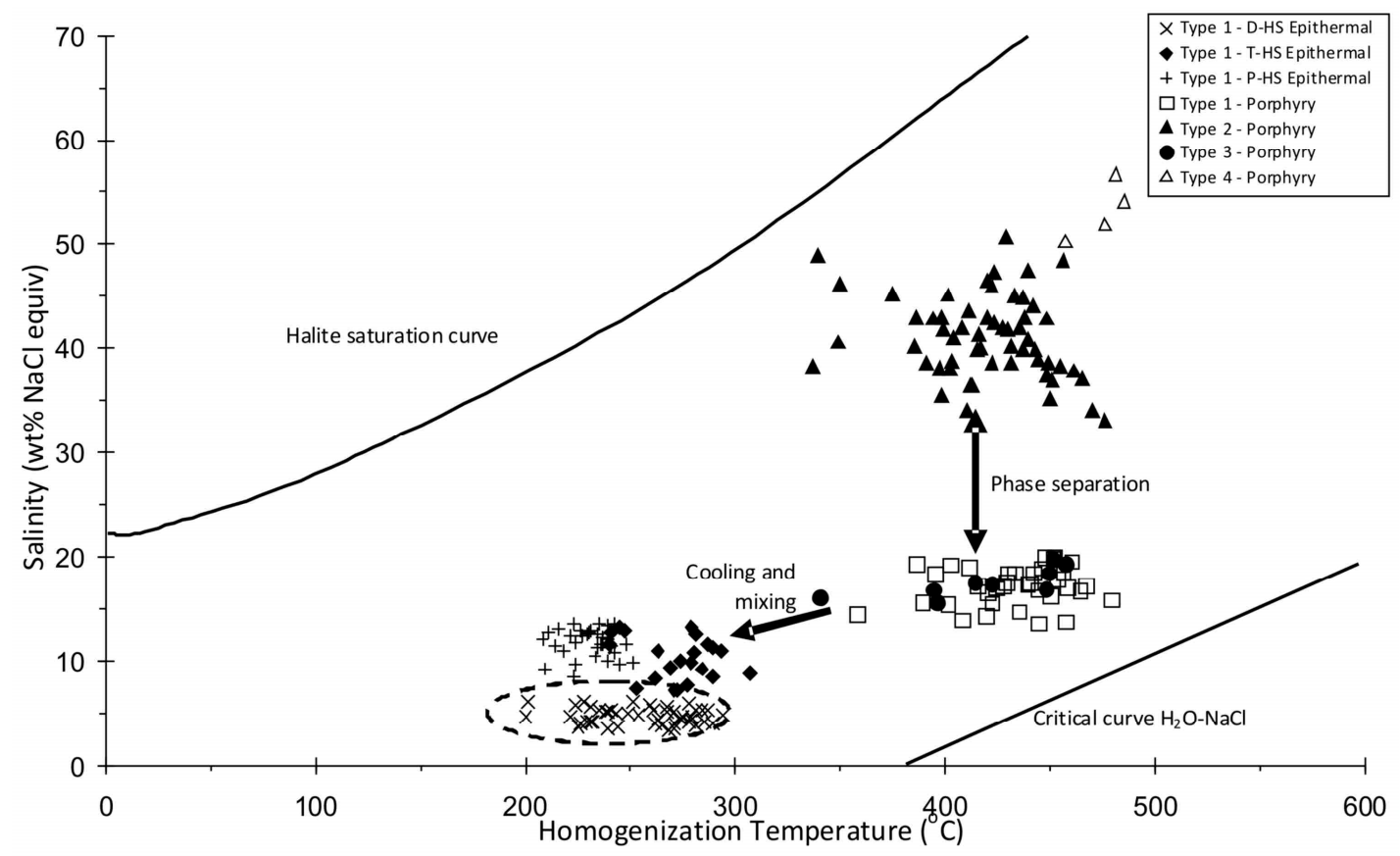

Figure 6. Homogenization temperatures versus salinity plot for the fluid inclusions from the Plavica $\mathrm{Au}-\mathrm{Ag}-\mathrm{Cu}$ deposit. Salinity was calculated by the equation of Bodnar [43]. Explanation abbreviations as in Figure 5.

The fluid inclusions in quartz from the HS epithermal mineralization (sample PLV 3581) show similar first melting temperatures of the ice with the porphyry style mineralization, demonstrating the presence of $\mathrm{K}^{+}, \mathrm{Ca}^{2+}, \mathrm{Fe}^{2+}$ or $\mathrm{Mg}^{2+}$ in addition to $\mathrm{Na}^{+}$. Temperatures of final ice melting $(-9.35$ to $-4.60{ }^{\circ} \mathrm{C}$ ) in quartz indicate salinities of 7.25 to $13.24 \mathrm{wt} \% \mathrm{NaCl}$ equiv. [43]. The homogenization temperatures (Th) range from 240 to $307^{\circ} \mathrm{C}$, with a maximum at $280{ }^{\circ} \mathrm{C}$ (Figure 5). The estimated densities for these fluids are $<0.90 \mathrm{~g} \cdot \mathrm{cm}^{-3}$ on the basis of the equation of state for volumetric properties of Archer [49].

\subsection{Microthermometric Data for the HS Epithermal Style Mineralization Proximal to the Porphyry Style Mineralization}

Microthermometric measurements in the epithermal mineralization from samples PLV 3590 and PLV 3591 were obtained from type 1 fluid inclusions in quartz (Table 1). Eutectic temperatures were around $-40^{\circ} \mathrm{C}$, suggesting the presence of $\mathrm{CaCl}_{2}, \mathrm{FeCl}_{2}$, and $\mathrm{MgCl}_{2}$ in addition to $\mathrm{NaCl}$ in the fluid [46]. Final ice melting temperatures of type 1 inclusions in quartz $\left(-9.67\right.$ to $\left.-5.49^{\circ} \mathrm{C}\right)$ corresponded to salinities of 8.50-13.59 $\mathrm{wt} \% \mathrm{NaCl}$ equiv. Values of Th ranged between 208 and $258^{\circ} \mathrm{C}$, with a peak at $240{ }^{\circ} \mathrm{C}$ (Figure 5). These values demonstrate a cooler but less saline fluid compared with the fluid related to the telescoped HS sulfidation epithermal mineralization (Figure 6).

\subsection{Microthermometric Data for the HS Epithermal Style Mineralization Distal to the Porphyry} Style Mineralization

The sample PLV 3586 from the borehole MRDD005 is probably at the periphery of the porphyry style mineralization and the fluid inclusions of type 1 in quartz showed extended homogenization temperatures, from 200 to $294{ }^{\circ} \mathrm{C}$ with a maximum at $270{ }^{\circ} \mathrm{C}$ (Table 1), overlapping those from the telescoped and the proximal HS epithermal mineralization (Figure 5). Initial melting temperatures 
were approximately $-40{ }^{\circ} \mathrm{C}$, implying that the fluid contained $\mathrm{NaCl}, \mathrm{CaCl}_{2}, \mathrm{FeCl}_{2}$, and $\mathrm{MgCl}_{2}$ [46]. The salinities obtained from the final ice melting temperatures $\left(-3.82\right.$ to $\left.-2.03{ }^{\circ} \mathrm{C}\right)$ varied from 3.33 to $6.11 \mathrm{wt} \% \mathrm{NaCl}$ equiv., demonstrating a more dilute fluid with a meteoric origin and only a small contribution of a magmatic input.

\section{Discussion}

Alderton and Serafimovski [11] and Serafimovski et al. [17] classified the Plavica Au-Ag-Cu deposit as an HS epithermal style mineralization, although they mentioned the presence of $\mathrm{Cu}$-sulfides, magnetite, and molybdenite associated with sericitic alteration, which were encountered by the only deep borehole. Therefore, they suggested that Plavica is underlain at depth by a porphyry style mineralization.

The studied fluid inclusions indicate that mineralization in Plavica formed over broad ranges of temperature and salinity. This reflects multiple hydrothermal events rather than one prolonged event. On the basis of the fluid inclusion data for the sample PLV 3583 from the drill hole PNDD014 (depth: $460 \mathrm{~m}$ ), an early magmatic fluid, exsolving at 700 to $800{ }^{\circ} \mathrm{C}$ at shallow depth from the crystallizing intrusion, in the porphyry style veins, dissociated into a high saline (33-57 $\mathrm{wt} \% \mathrm{NaCl}$ equiv.) brine and a moderate saline (15.60 to $17.59 \mathrm{wt} \% \mathrm{NaCl}$ equiv.) vapor phase. This process evolved at relatively high temperatures (mainly $380-500{ }^{\circ} \mathrm{C}$, with a peak at $440{ }^{\circ} \mathrm{C}$ ) under boiling conditions (Figure 6). The moderate salinities (13.59 to $19.90 \mathrm{wt} \% \mathrm{NaCl}$ equiv.) of type 1 and 3 fluid inclusions in the porphyry style veins from Plavica are not common for porphyry type deposits. Normally, salinities of liquid or vapor rich inclusions are low (5 to $12 \mathrm{wt} \% \mathrm{NaCl}$ equiv.) and represent the primary exsolved magmatic fluids from a crystallizing magma [50,51]. However, in several porphyry type deposits, relatively higher salinities (up to $20 \mathrm{wt} \% \mathrm{NaCl}$ equiv.) have been observed (e.g., Dalli porphyry $\mathrm{Cu}$-Au deposit, Central Iran [52]; Collahuasi porphyry Cu-Mo deposit, northern Chile [53]; Shabutai porphyry Mo deposit, Inner Mongolia [54]; Thames porphyry Cu-Mo-Au deposit, New Zealand [55]) and have been discussed in details by Bodnar et al. [56].

According to Brathwaite et al. [55], the moderate saline (up to $20 \mathrm{wt} \% \mathrm{NaCl}$ equiv.) liquid-rich fluid inclusions (Type 1 in Plavica) represent a fluid that exsolved from the magma. In this case, the fluid cools across the plastic-brittle boundary deformation generating moderate temperature-salinity vaporand liquid-rich inclusions and does not form halite-bearing fluid inclusions [55]. Brittle fracturing, which generates the veins and stockworks in the porphyry systems, results in decompression from lithostatic to hydrostatic conditions and incursion of meteoric water, which is responsible for the sericitic alteration $[51,55]$.

The ore-forming fluid conditions described here from the deep levels of the Plavica system are similar to those of many porphyry-style deposits, where mineral deposition is associated with a rapid reduction in metal solubilities as moderately saline supercritical fluids or vapors or hypersaline liquid condensates ascend from the source magma [6]. This temperature interval is critical because over 400 ${ }^{\circ} \mathrm{C}, \mathrm{SO}_{2}$ in the fluid phase begins to form $\mathrm{H}_{2} \mathrm{~S}$ and $\mathrm{H}_{2} \mathrm{SO}_{4}$. This mechanism results in the precipitation of pyrite, molybdenite, chalcopyrite, and bornite, from an increasingly acidic fluid, which is associated with the progressive change from sericitic, through argillic to advanced argillic alteration [6].

The trapping pressures of the fluid inclusions from the porphyry type veins can be approximately estimated, suggesting that the fluid inclusions were trapped under boiling conditions in the $\mathrm{NaCl}-\mathrm{H}_{2} \mathrm{O}$ system. On the basis of the homogenization temperatures and the equation of Reference [49], the minimum trapping pressures for type 2 inclusions range from 100 to 430 bars, and for type 3 inclusions, from 140 to 460 bars. These pressures show a maximum depth of ore formation of $1.7 \mathrm{~km}$ under lithostatic pressures.

Fluid inclusion data of the samples PLV 3583, PLV 3590, PLV 3591, and PLV 3581 from the drill holes PNDD014, PNDD007, and PNDD005, respectively, suggest that HS mineralization was deposited from moderate to low salinity (3-14 $\mathrm{wt} \% \mathrm{NaCl}$ equiv.) fluids at temperatures $<300{ }^{\circ} \mathrm{C}$ (Figure 6). The estimated minimum trapping pressures calculated from the measured Th for the studied samples 
range between 0.01 and $0.09 \mathrm{kbar}$, which corresponds to paleo-depths up to $300 \mathrm{~m}$ under lithostatic conditions. Due to the shallow epithermal environment of the mineralization formation, the pressure correction is likely to be $<10^{\circ} \mathrm{C}$ (e.g., [57]).

Fluid salinities and temperatures obtained for Plavica fit within the spectrum of fluid characteristics (salinities from $<1$ to $45 \mathrm{wt} \% \mathrm{NaCl}$ equiv.) suggested for several $\mathrm{HS}$ deposits elsewhere (e.g., [1,41]). A few fluid inclusions studies on enargite at Julcani, Peru, Lepanto, Radtka and Chelopech, and Bor, Serbia describe salinities within the range of 5 to $20 \mathrm{wt} \% \mathrm{NaCl}$ equiv. (e.g., [58]), similar to those found at Plavica in the present study.

On the basis of previous studies, especially of stable isotope data, the origin of the hydrothermal fluids responsible for the porphyry and the HS mineralization at Plavica can be suggested, with similar magmatic vapor, magmatic brine, and unseparated magmatic fluid all having been proposed [58]. At Plavica, these later-stage magmatic-hydrothermal fluids may have contracted from the original supercritical fluid to the liquid phase upon cooling at pressure [6,41], or by vapor expansion under low-pressure conditions from very low density vapors, which led to condensation, super-saturation, and mineral deposition as proposed by Henley and Berger [59].

\section{Conclusions}

Fluid inclusions from the deep levels of the Plavica system (e.g., $460 \mathrm{~m}$, drill hole PNDD014) revealed an early magmatic brine in porphyry style veins with a high salinity (33-57 wt $\% \mathrm{NaCl}$ equiv.), which coexists with a lower salinity (14 to $20 \mathrm{wt} \% \mathrm{NaCl}$ equiv.) vapor dominated fluid, at relatively high temperatures $\left(380-500{ }^{\circ} \mathrm{C}\right)$ under boiling conditions. The porphyry type mineralization was formed at a maximum depth of $1.7 \mathrm{~km}$. At lower depths (40-265 m, drill holes PNDD014, PNDD007, MRDD005), the fluid inclusions showed that the HS mineralization was deposited from moderate to low salinity (3-14 $\mathrm{wt} \% \mathrm{NaCl}$ equiv.) fluids at temperatures $<300{ }^{\circ} \mathrm{C}$ (Figure 6), under low pressures (maximum depth of $300 \mathrm{~m}$ ).

Author Contributions: Conceptualization, V.M. and P.V.; Methods, V.M.; Investigation, V.M., P.V., T.S., and G.T.; Data Curation, V.M. and P.V.; Writing—Original Draft Preparation, V.M., P.V., T.S., and G.T.; Writing—Review and Editing, V.M., P.V., T.S., and G.T.

Funding: This research received no external funding.

Acknowledgments: We would like to thank the three anonymous reviewers and the Academic Editor of Geosciences, Paul Mueller, for their constructive and useful comments, which improved the initial manuscript. The mining company "Genesis Resources International Ltd." is also appreciated for providing us the samples.

Conflicts of Interest: The authors declare no conflict of interest.

\section{References}

1. Arribas, A. Characteristics of high sulfidation epithermal deposits, and their relation to magmatic fluid. Mineral. Assoc. Can. Short Course 1995, 23, 419-455.

2. Heinrich, C.A.; Driesner, T.; Stefánsson, A.; Seward, T.M. Magmatic vapor contraction and the transport of gold from the porphyry environment to epithermal ore deposits. Geology 2004, 32, 761-764. [CrossRef]

3. Sillitoe, R.H. Porphyry copper systems. Econ. Geol. 2010, 105, 3-41. [CrossRef]

4. Chang, Z.; Hedenquist, J.W.; White, N.C.; Cooke, D.R.; Roach, M.; Deyell, C.L.; Garcia, J., Jr; Gemmell, J.B.; McKnight, S.; Cuison, A.L. Exploration tools for linked porphyry and epithermal deposits: Example from the Mankayan intrusion-centered Cu-Au district, Luzon, Philippines. Econ. Geol. 2011, 106, 1365-1398. [CrossRef]

5. Seedorff, E.; Dilles, J.H.; Proffett, J.M., Jr.; Einaudi, M.T.; Zurcher, L.; Stavast, W.J.A.; Johnson, D.A.; Barton, M.D. Porphyry deposits: Characteristics and origin of hypogene features. Econ. Geol. 2005, 100, 251-298.

6. Richards, J.P. Magmatic to hydrothermal metal fluxes in convergent and collided margins. Ore Geol. Rev. 2011, 40, 1-26. [CrossRef] 
7. Sillitoe, R.H. Gold deposits in western Pacific island arcs: The magmatic connection. Econ. Geol. Monogr. 1989, 6, 266-283.

8. Sillitoe, R.H. Gold-rich porphyry deposits: Descriptive and genetic models and their role in exploration and discovery. Rev. Econ. Geol. 2000, 13, 315-345.

9. Serafimovski, T. Metallogeny of the zone Lece-Chalkidiki. Ph.D. Thesis, Faculty of Mining and Geology-Štip, Štip, Macedonia, 1990; p. 380. (In Macedonian)

10. Serafimovski, T. Structural-Metallogenic Features of the Lece-Chalkidiki Zone: Types of Mineral Deposit and Distribution; Special Issue 2; University of St Cyril and Methodius: Štip, Macedonia, 1993; p. 325.

11. Alderton, H.M.D.; Serafimovski, T. The geology and genesis of the Plavica copper-gold deposit, Macedonia. Appl. Earth Sci. (Trans. Inst. Min. Metall. B) 2007, 116, 94-105. [CrossRef]

12. Serafimovski, T.; Tasev, G. Ore-Microscopic Study of Samples from the Plavica Deposit; Department of Mineral Deposits, Faculty of Natural and Technical Sciences, University “Goce Delčev”: Štip, Macedonia, 2013; p. 411. (In Macedonian)

13. Stefanova, V.; Volkov, A.V.; Serafimovski, T.; Sidorov, A.A. Native Gold from the Plavica Epithermal Deposit, Republic of Macedonia. Dokl. Earth Sci. 2013, 451, 818-823. [CrossRef]

14. Zlatkov, G.; Tasev, G.; Stefanova, V.; Bogdanov, K.; Serafimovski, T. Composition of some major mineral phases from the Plavica epithermal gold deposit, eastern Macedonia. Geol. Maced. 2014, 28, 149-163.

15. Ivanovski, I.; Serafimovski, D.; Tasev, G.; Serafimovski, T. 3D modeling of the Plavica Au-Cu molymetallic deposit, Republic of Macedonia. Geol. Maced. 2015, 29, 63-74.

16. Serafimovski, T.; Zlatkov, G.; Tasev, G.; Stefanova, V. Cu-Au minerals and transformed mineral phases in the oxidation zone of the Plavica ore deposit, Eastern Macedonia. Geol. Maced. 2016, 30, 5-21.

17. Serafimovski, T.; Volkov, V.A.; Serafimovski, D.; Tasev, G.; Ivanovski, I.Y.; Murashov, K. Plavica Epithermal Au-Ag-Cu Deposit in Eastern Macedonia: Geology and 3D Model of Valuable Component Distribution in Ore. Geol. Ore Depos. 2017, 59, 296-304. [CrossRef]

18. Draganov, D. The Coins of Macedonian Kings I: From Alexander I to Alexander III; Ya: Yambol, Bulgaria, 2000; p. 220. (In Bulgarian)

19. Terzić, M.; Pavlović, D.; Kuzmanović, M.; Obradović, S. Calculation of ore Reserves within the Polymetallic Deposit Plavica-Zlatica; SOUR RTB Bor RO Copper Institute: Bor, Serbia, 1986; p. 66. (In Serbian)

20. Gaze, R. Plavica Gold Project: Mineral Resource Estimate; Annual Report; Golder Associates: London, UK, 2017; p. 78.

21. Mijalković, N.; Pešić, D. Geological and petrological features of the NE part of the Kratovo-Zletovo area. In Proceedings of the VI Counseling of Geologists of Yugoslavia, Ohrid, Macedonia; 1966; pp. 158-170. (In Serbian)

22. Marković, M. Contribution to the Knowledge of Volcanic Morphology of the Kratovo-Zletovo Area; Annales Géologiques de la Peninsule Balkanique: Belgrade, Serbia, 1971; p. 36. (In Serbian)

23. Ivanov, T.; Denkovski, Đ. Geology of the Plavica-Zlatica deposit, Kratovo-Zletovo. In Proceedings of the 9th Congress of Geologists of Yugoslavia, Sarajevo, Bosnia and Herzegovina, October 1978; pp. 767-777. (In Macedonian)

24. Drovenik, M.; Pezdic, J.; Rakić, S. The sulfur isotopic composition of pyrite from borehole ZB-24 Plavica, Zletovo-Kratovo volcanic area. Rud. Metal. Zb. 1983, 30, 69-76, (In Slovenian, with English Summary).

25. Serafimovski, T.; Rakic, S. New Geochemical data concerning gold related to silification zones in the Plavica volcanic structure, Eastern Macedonia. In Proceedings of the 5th Biennial of the SGA Meeting, London, UK, 22-25 August 1999; pp. 585-588.

26. Ivanov, T.; Denkovski, Đ. Hydrothermal alterations in the Plavica-Zlatica porphyry copper deposit in the Kratovo-Zletovo volcanic area. In Symposia of Alteration of Rocks and Minerals, 100 years of Geological School and Science in Serbia; Faculty of Mining and Geology, University of Belgrade: Beograd, Serbia, 1980; pp. 291-302. (In Macedonian)

27. Stojanov, R. Volcanic cupola Plavica and polymetallic mineralizations and alterations within. In Symposia of alteration of rocks and minerals, 100 years of Geological School and Science in Serbia; Faculty of Mining and Geology, University of Belgrade: Beograd, Serbia, 1980; pp. 139-162. (In Macedonian)

28. Serafimovski, T.; Zlatkov, G.; Tasev, G.; Ivanovski, I. Polymetallic ore paragenesis in the Plavica ore deposit, Eastern Macedonia. In Proceedings of the 15th International Multidisciplinary Scientific Geoconference SGEM 2015, Albena, Bulgaria, 16-25 June 2015; pp. 369-376. 
29. Serafimovski, T. Elaborate of Detailed Geological Exploration with Calculation of Geological Ore Reserves of Mineral Components Copper and Gold at the Plavica Locality, Kratovo; University “Goce Delcev"-Štip, Faculty of Natural and Technical Sciences for Investor Genesis Resources International Ltd.: Štip, Macedonia, 2014; p. 431.

30. Serafimovski, T. Annex to Elaborate of Detailed Geological Exploration with Calculation of Geological Ore Reserves of Mineral Components Copper and Gold at the Plavica Locality, Kratovo; University "Goce Delcev"-Štip, Faculty of Natural and Technical Sciences for Investor Genesis Resources International Ltd.: Štip, Macedonia, 2014; p. 249.

31. Melfos, V.; Voudouris, P. Fluid evolution in Tertiary magmatic-hydrothermal ore systems at the Rhodope metallogenic province, NE Greece. A review. Geol. Croat. 2016, 69, 157-167. [CrossRef]

32. Tsirambides, A.; Filippidis, A. Gold metallogeny of the Serbomacedonian-Rhodope metallogenic belt (SRMB). Bull. Geol. Soc. Greece 2016, 50, 2037-2046. [CrossRef]

33. Melfos, V.; Voudouris, P. Cenozoic metallogeny of Greece and potential for precious, critical and rare metals exploration. Ore Geol. Rev. 2017, 89, 1030-1057. [CrossRef]

34. Menant, A.; Jolivet, L.; Tuduri, J.; Loiselet, C.; Bertrand, G.; Guillou-Frottier, L. 3D subduction dynamics: A first-order parameter of the transition from copper-to gold-rich deposits in the eastern Mediterranean region. Ore Geol. Rev. 2018, 94, 118-135. [CrossRef]

35. Serafimovski, T.; Boev, B. Metallogeny of the Kratovo-Zletovo volcano-intrusive complex. In The Formation of the Geologic Framework of Serbia and the Adjacent Regions; Knezevic, D., Krstic, B.D., Eds.; Faculty of Mining and Geology of the University of Belgrade and Committee for Geodynamics of the Serbian Academy of Sciences and Arts: Belgarde, Serbia, 1996; pp. 347-352.

36. Boev, B.; Yanev, Y. Tertiary magmatism within the Republic of Macedonia: A review. Acta Vulcuanologica 2001, 13, 57-71.

37. Petkovic, M.; Romic, K. Structural-Volcanological Study with Determination of the Plavica's Erosion Level; Professional Fund of RIK-Sileks: Kratovo, Yugoslavia, 1977; p. 81. (In Serbian)

38. Reid, D.; Patterson, J.; McLeod, A. Mineral Resources Estimate Report, Plavica Project, Macedonia. Report of Genesis Resources Ltd.. Available online: https://genesisresourcesltd.com.au/attachments / investor-information/resource-reports / 201612\%20-\%20Ravensgate\%20Plavica\%20Report.pdf (accessed on 13 February 2019).

39. Serafimovski, T.; Rakic, S. The secondary quartzites hosting gold mineralization in the Crn Vrv-Plavica volcanic area. Geol. Maced. 1998, 12, 9-21.

40. Deen, J.A.; Rye, R.O.; Munoz, J.L.; Drexler, J.W. The magmatic hydrothermal system at Julcani, Peru: Evidence from fluid inclusions and hydrogen and oxygen isotopes. Econ. Geol. 1994, 89, 1924-1938. [CrossRef]

41. Hedenquist, J.W.; Matsuhisa, Y.; Izawa, E.; White, N.C.; Giggenbach, W.F.; Aoki, M. Geology, geochemistry, and origin of high sulfidation $\mathrm{Cu}-\mathrm{Au}$ mineralization in the Nansatsu district, Japan. Econ. Geol. 1994, 89, 1-30. [CrossRef]

42. Brown, P.E. FLINCOR; a microcomputer program for the reduction and investigation of fluid-inclusion data. Am. Mineral. 1989, 74, 1390-1393.

43. Bodnar, R.J. Revised equation and table for determining the freezing point depression of $\mathrm{H}_{2} \mathrm{O}-\mathrm{NaCl}$ solutions. Geochim. Et Cosmochim. Acta 1993, 57, 683-684. [CrossRef]

44. Roedder, E. Fluid Inclusions; Reviews in Mineralogy; Mineralogical Society of America: Chantilly, VA, USA, 1984; Volume 12, p. 646.

45. Bodnar, R.J. Introduction to fluid inclusions. In: Fluid inclusions: Analysis and interpretation. Mineral. Assoc. Can. Short Course 2003, 32, 1-8.

46. Shepherd, T.; Rankin, A.; Alderton, D. A Practical Guide to Fluid Inclusion Studies; Blackie and Son: Glasgow, UK, 1985; p. 239.

47. Potter, R.W.; Clynne, M.A.; Brown, D.L. Freezing point depression of aqueous sodium chloride solutions. Econ. Geol. 1978, 73, 284-285. [CrossRef]

48. Bodnar, R.J. Fluid-inclusion evidence for a magmatic source of metals in porphyry copper deposits. Mineral. Assoc. Can. Short Course 1995, 23, 139-152.

49. Archer, D.G. Thermodynamic properties of the $\mathrm{NaCl}+\mathrm{H}_{2} \mathrm{O}$ system. II. Thermodynamic properties of $\mathrm{NaCl}$ (aq), NaCl-2 $\mathrm{H}_{2}$ (cr), and phase equilibria. J. Phys. Chem. Ref. Data 1992, 21, 793-829. [CrossRef]

50. Burnham, C.W. Magmas and hydrothermal systems. In Geochemistry of Hydrothermal Ore Deposits; Barnes, H.L., Ed.; John Wiley \& Sons, Inc.: New York, NY, USA, 1997; pp. 63-123. 
51. Audétat, A.; Pettke, T.; Heinrich, C.A.; Bodnar, R.J. Special paper: The composition of magmatic-hydrothermal fluids in barren and mineralized intrusions. Econ. Geol. 2008, 103, 877-908. [CrossRef]

52. Zarasvandi, A.; Rezaei, M.; Raith, J.; Lentz, D.; Azimzadeh, A.M.; Pourkaseb, H. Geochemistry and fluid characteristics of the Dalli porphyry Cu-Au deposit, Central Iran. J. Asian Earth Sci. 2015, 111, 175-191. [CrossRef]

53. Masterman, G.J.; Cooke, D.R.; Berry, R.F.; Walshe, J.L.; Lee, A.W.; Clark, A.H. Fluid chemistry, structural setting, and emplacement history of the Rosario $\mathrm{Cu}-\mathrm{Mo}$ porphyry and $\mathrm{Cu}-\mathrm{Ag}-\mathrm{Au}$ epithermal veins, Collahuasi district, northern Chile. Econ. Geol. 2005, 100, 835-862. [CrossRef]

54. Zhou, Y.; Lai, Y.; Shu, Q.; Sun, Y.; Xu, J.; Liang, Y. Geochronology and fluid inclusion study of the Shabutai porphyry Mo deposit, Inner Mongolia. Ore Geol. Rev. 2017, 81, 745-759. [CrossRef]

55. Brathwaite, R.L.; Simpson, M.; Faure, K.; Skinner, D. Telescoped porphyry Cu-Mo-Au mineralisation, advanced argillic alteration and quartz-sulphide-gold-anhydrite veins in the Thames District, New Zealand. Miner. Depos. 2001, 36, 623-640. [CrossRef]

56. Bodnar, R.J.; Lecumberri-Sanchez, P.; Moncada, D.; Steele-MacInnis, M. Fluid inclusions in hydrothermal ore deposits. In Treatise on Geochemistry, 2nd ed.; Elsevier: Oxford, UK, 2014; pp. 119-142.

57. Bodnar, R.J.; Reynolds, T.J.; Kuehn, C.A. Fluid-Inclusion systematics in epithermal systems. Rev. Econ. Geol. 1985, 2, 73-97.

58. Sillitoe, R.H.; Hedenquist, J.W. Linkages between volcanotectonic settings, ore-fluid compositions, and epithermal precious metal deposits. Soc. Econ. Geol. Spec. Publ. 2003, 10, 315-343.

59. Henley, R.W.; Berger, B.R. Magmatic-vapor expansion and the formation of high sulfidation gold deposits: Chemical controls on alteration and mineralization. Ore Geol. Rev. 2011, 39, 53-74. [CrossRef]

(C) 2019 by the authors. Licensee MDPI, Basel, Switzerland. This article is an open access article distributed under the terms and conditions of the Creative Commons Attribution (CC BY) license (http:/ / creativecommons.org/licenses/by/4.0/). 